Portland State University

PDXScholar

1971

\title{
The father's role in treatment; a survey of selected social service programs
}

Joanne Robertson

Portland State University

Follow this and additional works at: https://pdxscholar.library.pdx.edu/open_access_etds

Part of the Social Work Commons

Let us know how access to this document benefits you.

\section{Recommended Citation}

Robertson, Joanne, "The father's role in treatment; a survey of selected social service programs" (1971). Dissertations and Theses. Paper 1526.

https://doi.org/10.15760/etd.1524

This Thesis is brought to you for free and open access. It has been accepted for inclusion in Dissertations and Theses by an authorized administrator of PDXScholar. Please contact us if we can make this document more accessible: pdxscholar@pdx.edu. 
AN ABSTRACT OF THE THESIS OF Joanne B. Robertson for the Naster in Sooial Work presented May 15, 1971.

Title: The Father's Role in Treatment: A Survey of Selected Social Service Programs.

APPROVED BY MEMBERS OF THE THESIS COMMITTEE:
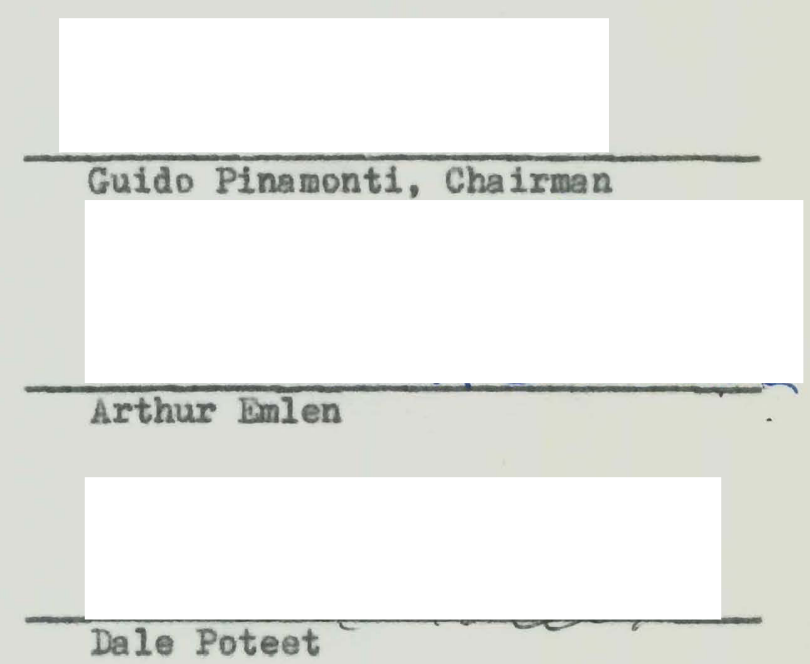

This is a descriptive, partially exploratory study which examined the data obtained from interviews with social workers in selected social welfare programs in regard to the father in treatment. Explored were descriptive information concerning the agency's characteristics, the type and extent of treatment offered, the involvement or resistance of the father in therapy, and the provision made for a surrogate male model in the event of the father's absence. 
The literature revealed that currently there is a growing body of knowledge and theory related to the father's role in the psychosocial development of the child and the consequences of his absence. It might be noted that in the past more attention has been given in theory and research to the mother's role.

Through personal interviews with one professionsl social worker in each of eighteen selected programs in Multnous County data were obtained with a data collection schedule used as a guide.

The findings indicated that the father was intereated in his child's development and more wlling to participate in treatment than is genera $11 \mathrm{y}$ appreciated.

Although the philosophy and policy of all of the agencies recognized the importance of the father in therapy, in actual practice only a minority had been able to implement this in treatment to an extensive degree due to the lack of ataff time and training. A few programs, however, did report a ratio of staff to clients which enabled them to sustoin the father and his family in intensive, seaningful therapy. There are indications that more flexible agency hours need to be implemented to better enable social workers to involve the father.

An energing emphasis on innovative new methods such as total family group therapy which tends to involve the father in therapy, was reficwoted in the study. The dats indicated that several agencies in the last few years have begun to use new methods to a significant degree, with the leadership of trained social work therspists, and that other agencies are using nev wethods in a moderate degree or are planning to implement these methods in the near future. 
The majority of agencies did recognize the need for the use of substitute male models, in some cases of father absence, but they found few available resources for the provision of this service. Although this was a general, descriptive paper only, some trends in practice regarding the father did emerge. Indications are that the father has a vital interest in his child's development, that he has shown an increasing willingness to become involved in therapy, and that there is a growing emphasis, in agencies, for the use of new treatment methods which emphasize the involvement of the father. 
THE FATHER'S ROLE IN TREATMINT: A SURVEY OF SELECTED SOCIAL SERVICE PROGRAMS

\section{by}

JOANNE ROBERISON

A thesis submitted in partial fulfillment of the requirements for the degree of MASTER OF SOCIAL WORK Portland State University 1971 
TO THE OFFICE OF GRADUATE STUDIES:

The members of the Comittee approve the thesis of Joanne B. Robertson presented May 15, 1971.
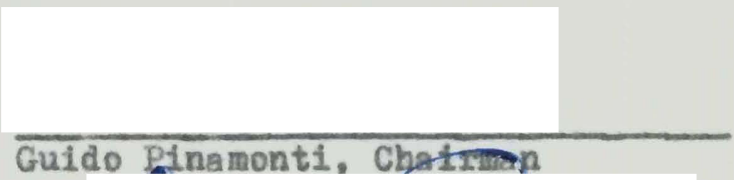

Arthur Emlen

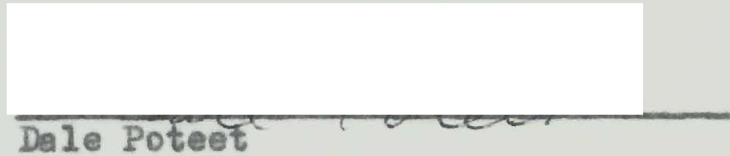

APPROVED:

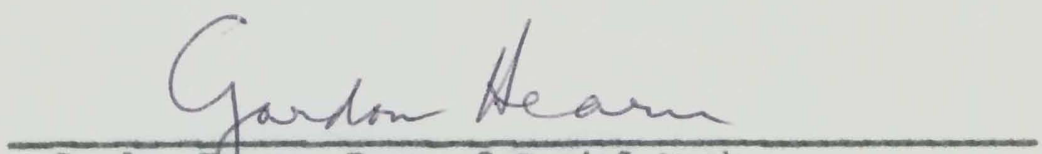

Gordon Hegrn, Dean of Social Work

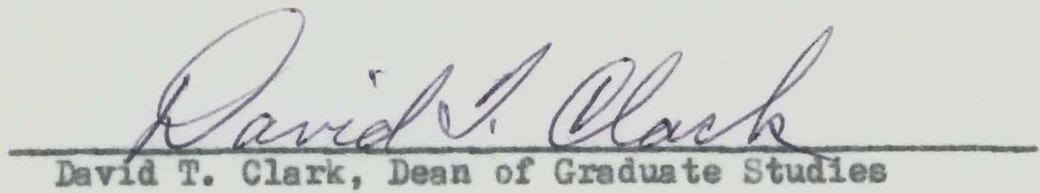

May 15, 1971 
TABLE OF CONTENTS

PAGE

\section{CHAPTER}

I IWRRODUCTION............................... I

The Father's Role in the Child's Developsent and

the Effect of His Absence ............... 2

Treatments Its History and

the Involvement of the

Father ..............................

17 METHOD AND DESICN......................... 18

Nature of the study..................... 18

Taxget Population...................... 18

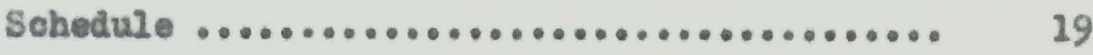

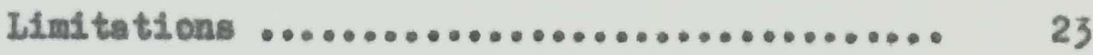

III ANALYSIS OF THE DATA .......................... 25

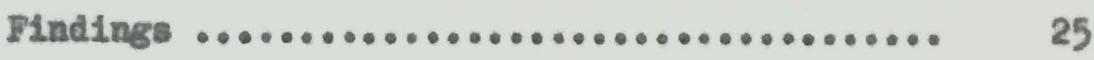

Administrative Dectors ............. 26

Agenoy Philosophy and Programs ....... 30

The Father in Treatment ............ 39

Dse of a Supplemental Vale Model....... 42

IV covcuestows .............................. 44

A SELWCTED BIBLIOGRAPHY .......................... 47 
CHAPTER

APPENDTCES

A LETTER TO AGENCY ADMINISTRATORS..............

B IIST OF AGHCIES AND THEIR

ADMINISTRATORS WHERE INTERVIEWS

WERE CONDUCTED.......................

C DATA COLLBCTION SCHEDULE

D DESCRIPTION OF TREATMEYT MODES 


\section{CHAPTER I}

\section{INTRODUCTION}

In the last two decades the behavioral and ohild development sciences have shown growing interest in the role of the father in the psychosocial development of the child. The tremendous focus on the mother has given way to growing interest in the father. A corollary interest has been evident in the helping professions such as peychiatry, psychology and social work. This is evidenced by the increasing use of family group therapy and other innovative new treatment methods which involve the father in working on the family's problems.

Social work agencies have also reflected this concern in regard to the father by their efforts to involve him in treatment. This study attempts to find out to what extent the father participates in treatment and what the theoretical basis is which lies behind this involvement.

Thus far published research on the father has focused on such aspects as his role as head of the family, the impact of industrialization on his function, his influence on the child's psychosocial development, the consequences of his absence or disinterest in the child, and his involvement in treatment. The remainder of this chapter will examine the latter three of these facets of the paternal role in more detail. 


\section{THE FATHER'S ROLE IN THE CHILD'S DEVELOPMEWT AND THE EFTECTS OF HIS $\triangle$ ABSENCE}

At every age the personality of the child is shaped by sooial relationships. The efrcles of the scolety widen about the child, from the primary unit of the infant and mother, to father, to alblinge, to neighborhood, and then to peers in play activities and sohool. A child: ideas of whet he wants and needs, standards of behavior and valuations of atas and achievenent, the sense of paycholosiesl vell-being or inbalince - all of these are fashoned, first by the attitudes and 1deas of the nother and father, and then by the growing number of people with whow he associates (Perlman, 1957, p. 9). Personality, as Perlman deseribed 1t, is the attitude or characteristic expression of himself which the child, snd then the adult, develops to deal with himself in the pursult of his conseicus and uneonscious gols. This personsity is largely set in the child's early experiences in the fanily (1bid., p. 18). According to Elkin (1960, p. 54), Mead (1956, p. 165), and Mitecherl1ch (1963, p. 302), one of the fundamental taaks of humen socialization, acoomplished wainly in the fandly setting, is the individual's secure initiation into his sexual role. English and Pearson (1963. p. 124), Feldman (1958, p. 23), aud Lidz et al. (1956, p. 329) point out that the family is the primary conveyor and teacher of the child and that this function is ainly covert. Sears, Rau, and Albert (1965. p. 272) oubmit that the gender roles are very broad and very subtle and that it would be difficult to imagine that any kind of direct tuition could provide for learning of such complicated behavioral 
an attitudinal patterns as the aspects of masculinity and femininity. These qualities which are absorbed quite early, usually by age five or six or even earlier, are highly resistant to latter modification. Mischerlich (1963, pp. 58-60) cited Harlow, Spitz, and Erikson's theories on the development of basic trust in the infant during the period of the first six to twelve months of life. The basis of the feeling of identity forms early. Those who have not had the experience of dependability in infancy clearly have a great obstacle in their path to find a growing understanding of their own identity through the turbulent years of development from stage to stage.

Erikson (1960, p. 44) emphasized that if the ego has gained a positive balance during the child's developmental crises, the setback of life will be less devasteting than if the balance, at one stage or another, was in the negative.

The rates of development and levels of intelligence vary among children at any given age, but the sequence of developwental stages from birth to maturity is the same for all children whether they are somewhat retaxded or exceptionslly bright (Wolff, 1969, p. 3).

Maler (1965, p. 142) reviewed Plaget's cognitive theory of the development of the personality which proposes that all mature aspects of behavior have their beginnings in infant behavior and evolve through subsequent patterns of development. In this theory developmental trends sre interrelated and interdependent and if maturity is achieved there hss been accomplished a total integration of all developmental trends. Rosenbaum (1970, p. 48 and p. 77) commented that wental functioning is learned and practiced and that for the first several years of life nearly 
all of the labeling, classifying, and evaluating of experience are patterned closely on parental modes. Children, at birth, do not know how to think logically; this skill is taught first by parents.

One of the persons with primary relationship to the young child is the father. In speaking of the father's importance in the ohild's stages of growth English and Pearson (1963, p. 116) commented that the presence of a visible father is most necessary during the period from birth to the age of six or seven, is less necessary but st111 very important during the latent period, and is less essential though still desirable during adolescence.

Nash (1965, p. 290) Indiosted that there is reason to argue that the major factor in boy's psychosexual development as a male person is his identification with his father or a father substitute, and that if it is to be effective, this identification must commence in infancy. The commonly held idea that the father is unimportant to the young child and that the mother's affection is all that is necessary to healthy personality development does not hold up. Indications are the a lack of male influence on the infant encourages the development of effeminate males which is not a trait valued by our culture.

Studies cited by Nash (ibid, pp. 281-285) appear to show that there are critical periods in souline development of the boy partioularly during the early childhood years (birth to three years). The time of the father's absence as a mo model appears to be a crucial factor as subjects have been reported to be less masouline if the father's absence occurred during the first four years of life. The time of weaning may be critical period in the boy's necessary transfer 
from mother to father.

Pederson (1966, p. 322) pointed out that some other studies suggested that the period in the child's development in which fatherabsence is a relevant variable could alsc extend to the oedipal period (three to five years) and to middle childhood (five to nine years) and that research and theory is inconsistant in pointing to single period as the one of greatest signiflcance.

Nash (1965, pp. 262-264) noted that in Western society, where so much child rearing is delegated to the mother, some fathers are hesitant to enter into the child-rearing relationship. Bigner (1970, p. 360) suggested that the mother can help increase paternal involvement with the children by creating occasions in which the father is encouraged to exercise his role. This might be posaible if certain tasks were the responsibility of the father. For example, be could romp with the chilaren while the mother was getting the dinner and later in the evening he could supervise the bed time preparations. He could also make an effort to Include the children at times in his tasks around the home and in his recreationa 1 activities.

The crucial event of the oedipal perlod for children of both sexes is the achievement of sexual identity as a male or female person. The boy has the difficult task of overcoming the primary identification with the mother and the ambivalent fear and hostility he has directed toward the father. He must learn to identify with his father. By being an available and adequate model of the male role the father gives his son the opportunity to incorporate a workable masculine image. The boy cannot grow in the image of the mother. A father figure, albeit a 
surrogate father or simply an 1deal of father figure which he can follow in his emotional development, is essential. A boy needs a father who can show the way in relating in a mesculine way to the mother (Jones, 1963. pp. 302-303; Lidz et a1., 1957, pp. 334-336). Rosenbaum (1970, p. 241) pointed out that although there is considerable evidence to suggest that gender-role identification, or conflicts about it, are already apparent by the age of two and one half or three yes $x$, the joining of many disperate elements of gender identification take place during the phallic stage. This confliet is again worked through on a more advanced level in adolescense.

To the fomale child, for whom identity is based mostly on the mother, the father's presence is still vital to her emotional and socisl development. Ostrovsky (1962, p. 22) cited the findings of Sears, Pintler, and Seers which indicate that the father is important to the girl for her relationehips, present and future, with men and boys. The father's exemple of his role forme the besis for her later emotions 1 attachnents and for her acceptance of her female role. She needs to know from her father or other male models that her sex has value. The infrequent presence or the total absence of the father is detrimental to the girl's development as it limits her comprehension of the le role, it similarly dees to the boy, and provides little opportunity for her to work on rapport and satisfactory emotional ties with him. The resultant limitation of experienoe inhibits her chances to develop her capacities for affection and to achieve the normal integration of this affection for the father, so necessary in the preparation of her future role as woman. The need for interest, attention, and concern 
on the part of the fother is as necessary to the girl as to the boy and must begin esrly in 11fe (Klein, 1968, p. 138).

B111er (1968, p. 1006); Ostroveky (1962, p. 147); Thomes (1969, p. 89); and Wolff (1969, pp. 86-87) are among the authors who have written on the effects of various types of father absence on the young child. They commented that the infrequent presence of the father in the howe or an occsional subst1tute male figure, as found in the case of the death of the father, does not permit the le child to identify himelf elearly with the mesculine role beyond the liaits of hie imadiate and infrequent contacts. The child needs a ralationship of graeter depth if he is to incorporate a well-integrated concept of the role which he hiraself will one day play and whlch he is already expected, to some extent, to portray. If the child has to gather fragments of experience and observations in order to construct an inage of the male figure, then it is not surprising If the image lacks completeness and integration.

Although in any realms the male adult plays predominant role in his society, his partioipation in child resing is many times minor. When the father is infrequently in the home, the intensity of the emotion:? relationship which a child may establish with his father w11l by 1 ts quality, help equalize the lack of frequency of contact, but short-1ived intense wowents of rapport with the father may not be able to compensate the chlid for a close and continuous contact (Ostrovsky, 1962, p. 146, and p. 20).

More far-reaching reverberations can be observed in the oases of children who are largely or completely deprived of father as is frequently the case in desertion, separation, divorce, over-seas m111tary 
service, long perlod residence in a mental hospital, prison, or death. The removal of a father brings yearning or oonflict to the boy or girl. It results in tension and often the child's exaggerated preoccupating in this realm interferes with his ability to freely enter new experiences. The intrapsychic conflict uses a laxge supply of energy and leaves the child with a diminished force to expend on the exploration of his environment or to maintain relationships with his peers and others (Fnglish and Pearson, 1963, pp. 114-117; and Ostrovsky, 1962, p. 156).

Another disadvantage of the absent father is the sense of inadequacy which the child may feel in relation to peers who have a complete family. The desire to be like others, in those areas which are reassuring and protective in nature, is a need of all human beings. This is especially true of ohildren. Studies of Bowlby showed that children seem to have atrong desire for a harmonious home life. LaPiere and Farnsworth found that the conflict between the desire for harmony and the reality of the fact that this way of Iife does not exist in his own 1ife, is difficult to accept and even more of a problem to resolve. It may lead to behavior problems and maladustment (Ostrovsky, 1962, p. 35 : and U. S. Department of Health, Education and Welfare, 1970, p. 70, and p. 97).

The child who is deprived of close and consiatent contact with the father or father figure is thus deprived of one of the nost essential experiences in his or her 11fes the feeling of love and protection and a sense of belonging usually associated with a normal father-child relationship. As Freud (1961, p. 19) comented, no need in childhood is stronger than the need for a father's protection. 
Some ways to help remedy the reduced presence or total absence of the masculine figure in the child's life are to employ at least as many men teachers as women teachers in the nursery school, kindergerten, and grade school levels. Also alternate male adults such as recreation leaders, tutors, "big brothers", social caseworkers, relatives and neighbors can be visible male models with whom the child can relate. (Bigner, 1970, p. 360; English and Pearson, 1963, p. 117; and U. S. Department of Health, Education, and Welfare, 1970, pp. 95-96).

Bigner (1970, p. 359) and Moynihan (U. S. Department of State, 1965, p. 48) in speaking of the black family in the urban ghetto stated that as the result of family disorganization, particularly the absence of the father, a large proportion of Negro children have not undergone the socialization which only a stable family can provide.

The findings on a study of Negro apprenticeship by the New York State Commission Against Discrimination in 1960 showed that Negro youth were seldom exposed to influences which can lead to apprenticeship. Hegroes were not apt to have a father, brother, uncle, or neighbor in a skilled occupation who could be a work model in their early years. Nor were black children likely to be in secondary schools where they received encouragement and direction from alternate male role models such as teachers (U. S. Department of State, 1965, p. 37).

Moynihan pointed to another study which related to the father, done by Deutch and Brown. This investigation of intelligence test results found that children, either white of negro, from homes whose fathers were present had significantly higher scores than children in homes without fathers (ibid. pp. 36-37). 
Bernard (1964, pp. 55-56) in a study of the economic and social adjustment of fatherless families found that the way of life of the underpaid, unskilled women laborers, using Welfare to aupplement their income for child rearing, was not a temporary response to events but a way of life "taught" by the parents to children due to extended economic and cultural deprivation. Herzog (U. S. Department of Health, Education, and Welfare, 1970, pp. 97-98) commented that it is a generally accepted proposition that fatily breakdown is the result of inadequate income and job akills for the father. She noted that the disorganization of the negro family is more frequent because of the greater social and economic disadvantages they suffer.

As in the case of the total or partial absence of the father, an emotionally destructive father can have a detrimental effect on the child. White (1956, p. 163) pointed out that a father's impatience and sarcasm can completely undermine the child's feeling of worth and competence. An important chapter in establishing self-esteem has already been written before the child leaves the family for the school.

Christian (1967, pp. 43-44) explored the relationship between the type of paternal involvement in child rearing and the development of learning problems in latency aged boys. The findings were consistent with the literature on this subject which showed that learning problems are related either to a hostile, punitive attitude, or to a passive, emotionally distant attitude on the part of the father toward the son in the pre-school years. Evidence indicated that the father's faulty relationship with the son did not provide an adequate opportunity for the son to identify with him. Christian felt that since these 
relationship characteristiog of the father interfere with the son's mastery of developmental tasks, it is clearly important to consider him in formulating appropriate treatment goals.

Golner (1964, pp. 534-539) in his study of identity and learning problems in latency age boys oited Erikson's formulation that the child from six to twelve years of age can be taught by his father and others the prerequisites for participation in the particular technology of his culture. He can be given the opportunity and the Iife task of forming an attitude of workmanship and of work participation. Golner explained that the boy's capacity to learn may be diminished if he has not resolved a neurotic conflict of the preschool years involving a faulty identification with his father. In treatment Golner found that if the father's masculine image was strengthened, his new attitudes would help free his son to achieve a sense of his own identity and to enable him to make an effort to learn.

Parad and Miller (1963, p. 201) and Redl and Wineman (1951, pp. 6061) pointed out that the disturbed father constitutes a poor model for Identification for the son and a poor example of the father's role for the daughter. Seriously distorted concepta of the parental function develop in the minds of the child unless some form of preventive intervention can be used to help the child learn normal parental roles. Some of the results of letting a child grow up in a disturbed family situation are impaired intellectual development, unstable marriage, inadequate capacity to bring up children, and suicide and crime. As Klein (1968, p. 135) pointed out the male identity of the father is recognized by the child from infancy and to serve as a reliable 
model, a father has to be seen, heard, and most important, be involved. Bigner (1970, p. 359) noted evidence found by Mussen and Distler in 1959 and Biller and Borstelmann in 1967 that sex-role development in boys is facilitated by a warm, rewarding, nurturant father who expresses involvement in his son's development of assertiveness and other culturally prescribed masculine traits.

Man in contemporary society is faced with many adjustments in his role as father because of changing social conditions. The status of the father characterizes him in terms of a set of obligations such as the provider of the material and emotional needs of the child and entails certain rights such as those to receive respect. The father, as is true with other status positions, is involved in a wide variety of role relations as an adult man, and it is possible for him to find himself with incompatible role requirements. This is becoming increasingly the plight of the twentieth-century man. The father may find himself unsure of what roles to enact with his child in contrast to his rural antecedent whose roles were strictly demarcated. He may have to search to find meaningful roles to play with his children (Landy, 1965, p. 560; and Strean, 1967, p. 78).

As Ackerman (1967, p. 8) described this dilema, the complementarity of family role relations can be out of kilter. The symbols of authority, the division of labor, the standards of closeness and sharing are confused. The roles of mother, father, and child are unclear. The consequence can be the discontinuity of the generations. Therapeutic intervention can be of help with these problems. 


\section{TREATMENT: ITS HISTORY AND THE INVOLVEMENT \\ OF THE FATHER}

Historically the family had been the major focus of social work even though, on the organizational level, services have often been segmented. The preoccupation with individual psychio processes which characterized helping efforts during the past decades unquestionably brought great advancement in theory and practice but these individual oriented techniques did not always accomplish the desired goals (Ackerman, Beatman, and Sherman, 1961, pp. 1-2).

One of the first movements to deviate from the traditional approach of treating just one member of the family was the child-guidance movement. As these therapists began to work both with the mother and the child, they came to realize that the father had a unique role in the functioning of the family. However, they did report him hard to reach, and usually were not able to engage him in therapy. Early in the childguidance movement the father was reported to feel that parenting was his wife's job more than his. He felt the mother was the one to be seen if a child showed a disturbance. The therapists tended to agree with the father's reasoning and consequently did not find it easy to help him see that his role in the family was important for the health of the child. As the movement developed further, the therapists gradually increased their emphasis on the essential role of "fathering" and the critical influence of the marital relationship on parenting (Satir, 1964, pp. 4-5).

Lippman (1962, p. vi) felt the child-guidance movement was a valuable trend as the familles of the children with emotional problems 
were given an opportunity to work with experts trained to help them. Satir, (1964, p. 4), in tracing the beginning of the treatment of the total family group, noted that early psychiatrists who worked with the intrapersonal aspeots of mental illness such as Sullivan and FrommReichman began to take note of the importance of the interpersonal aspects of mental illness in their clients.

The first family mental health elinic in this country was established at the Jewish Family Service in 1957 by Nathan Ackerman. The basic treatment modality was conjoint family therapy. The clinic was staffed by therapists who had been trained in the traditional individual method. At that time the conceptual frameworks for the description of family pathology, family interaction, and family dynamics were just beginning to be constructed (Kempsler and Savitsky, 1967, p. 127).

It became apparent to therapists who began to see the entire family together that it was easier in many cases to involve the father in that type of treatment. There wa a growing conviction among family therapists that both parents must be present for the treatment to be effective. They found that once the father became convinced that he was essential and that no one else could speak for him in therapy or in family life, he was quite frequently motivated to take part in treatment. (Sat1r, 1964, p. 5).

Nash (1965, pp. 262-263 and p. 292) and Morse (1968, pp. 281-284) referred to the tradition in our culture which tends to relegate responsibility for the management of the child to the mother. Morse noted that social scientists' knowledge has brosdened and that their focus in treatment moved from the isolated mother-child relationship to the 
interaction with the father and the complete family unit and its effect on the disturbed member.

Morse (ibid) mentioned that in her project's work with potients with juvenile rheumatoid arthritis, which has a large psychogenic element, fathers were given recognition as the head of the household. They were included in the process of diagnosis and treatment. The social worker obtained clues to the patterns of interaction between parents, and the parents and the patient during early interviews. Many fathers were found to be preoccupied with their own concern about their child's 11lness. They needed help to become more aware of the family's need for them to completely play a part in family leadership. If indicated, fathers were involved in personal interviews which were ego-supportive with the goal of strengthening the paternal role.

Morse (ibid) continued that as the staff became more aware of the peternal interest they were alert to opportunitios to mobilize this interest in a constructive way. The fathers were introduced to each other. They became effective educators, the experienced ones belping the ones with a newly admitted child. Caring for each other as well as the patient helped fathers haudle their feelings.

Helping a man to express his strength in a way that enables his wife and child to appreciate him more is important. Some fathers seem to lack knowledge in the content area of what it is like to be a father. The male therapist can sometimes act as a model of the peternal role and aid him to gain skill in that area. Otherwise the father may withdraw from his role function in an effort to minimize his influence which he sees as noxious on the child (zuk and Boszormenyl-Nagy, 1967, p. 182). 
The father can, of course, be beneficially engaged in any of the many modes of trestment. Elach therapist uses his own choice of treatment method or combination of modes according to his skill and the needs of the father and the family nembers.

Carter and Stuart (1970, p. 37) pointed out that social work has traditionally drawn on the theory and research of related disciplines in a continuing effort to enhance the effectiveness of its practice. They feel the introduction of new theories and knowledge have increased the range of practice strategies available to social workers in treatment. Brodey (1967, pp. 18-19) pointed out that in this time of change, all institutions, including the family, must freshen themselves or they will lose the war against obsolescence. He felt that the family process is at the heart of evolutionary human change and that genetic evolution alone is not fast enough to allow our society to gain control over tochnical progress. Developing new skills in the family function of child rearing is one means by which we can meet the challenge of our times.

This first chapter has examined some of the aspects of fathering that are discussed in the literature such as the role the father plays in the psychosocial development of the child, the consequences of his absence, and his involvement in treatment. This chapter also indicates the trend in therapy from the work with one individual to the beginning of the Child-Guidance movement which was important in involving both the mother and the child and then to the development of the total family or the maxital paix therapy both of which recognize that paternal involvement in treatment is desirable and essential to the work on fam1ly 
probleme (in cases when the father is in the home).

The following chapters of this descriptive study examine data on how social work agencies deal with the father in treatment. Data were collected through personal interviews with eighteen professional social workers in selected social service, health, and welfare programs in Jultnom County. Some of the following questions were explored: Do social workers in Multnomah County, who give service to children with emotional problems, recognize the importance of the father in the child's psychosocial development? Do they see the value of including the father in the treatment process? Is there an increasing use of types of innovative new treatment methods which consider the father as essential to the treatment process? What are the treatment modalities available? Do the fees of the agencies accommodate themselves to the low and average income father? What are the problems that local agencies and programs encounter if their goal is to involve the father in planning and therapy? Are these agencies able to implement, in actual practice, their philosophy and policy regarding the father's involvement in the treatment process? Are social workers aware of the consequences of the father's absence to the child and do they seek ways to ameliorate the loss? What conclusions can be drawn from this study of eurrent practice about social workers' recognition of the importance of the father and his involvement in therapy? The significance of the study lies in its attempt to answer these questions. 
CHAPTER II

METHOD AND DESIGN

\section{NATURE OF THE STUDY}

If the father's role is significant to the child's development, as various authors have suggested, then do social workers recognize his importance to the child, do they include him in therapy, and what services and resources do social agencies offer the father and his child? This is a descriptive, somewhat exploratory paper trying to examine these questions.

\section{TARGET POPULATION}

The writer deterwined io interview social workers in agencies serving children with emotional problems. It should be noted that some of these agencies were multiservice agencies and dealt with other types of problens as well. Both public and voluntary social agencies were included in the study.

As near as possible all of the agencies serving chlldren with emotional and social problems, listed in the Tri-County Community Council's booklet "Where To Turn", revised September 1968, were selected. See Appendix B for a list of these elghteen programs and their administrators. The names of social workers interviewed were not listed. There were two agencies in which two interviews were beld as they had two departments with specialized programs for children. For the purpose 
of avoiding confusion concerning sixteen agencies and eighteen separate social work interviews, in writing the findings they were referred to as eighteen agencies or programs.

A letter (see Appendix A) was sent to the administrator of each agency requesting that he assign a professional social worker to be the interviewee, if he was willing to copperate with the study. In the assignment of the social worker by the administrator it was hoped that the possibility that the interviewer could influence the choice of per-

sons to be interviewed would be omitted. The letter was worded in a way so as not to lead the focus of the interviewee toward the father, before the interview. It was hoped that comments on the father's involvement in therapy would be spontaneous and would not be influenced by what the interviewee might anticipate that the interviewer would wish to hear.

For the purposes of this study professional social workers were considered those who were graduates of an accredited school of social work. All ages of children were included in the study - that is from infancy through adolescence. In the use of terms, father and stepfather were considered the same in influence on the child, therefore the relationship of step-father was not specified. The terms of counseling, therapy, and treatment were used interchangeably unless otherwise defined.

\section{SCHEDULE}

Data collection by the interview method was done with the use of the data collection achedule found in Appendix C. The interviews were held at the various agencies at the social worker's convenience. The 
rationale for interviewing social workers from a data collection schedule, rather than a mailed questionnaire was that questionnaires would tend to be more easily set aside, answered incompletely, or answered with less thought and understanding. Findings from the schedule were reviewed for the social worker's and the agency's recognition of the father's role in the social and emotional development of the child, the effect of his absence, and his involvement in therapy.

The schedule was used in the interviews in an informal manner. An opportunity was given to the social worker to present information pertinent to the father in treatment in a spontaneous way in which he could bring out what he personally, and his agency felt was important or unique in their program.

The data collection schedule was composed of twenty-three subsections or questions. question \#I, the date, was recorded in order to show the time spen during which the findings were in effect. The inclusive dates of the interviews were from December 28th, 1970, through January 18th, 1971.

There are emerging methods of therapy which emphasize the importance of the father in treatment and special attention was paid to them in the analysis of the data because of their pertinence to the subject of this paper. Question 14 was designed to obtain information on treatment methods which might possibly be in use in the social agencies surveyed. Provision was made to obtain some indication of the frequency of their use. Appendix $D$ contains descriptions of treatment methods covered by this question. These definitions were taken from Ackerman (1967, p. 4 and p. 15), the Family and Children's service of Greater 
St. Louis (1968, pp. 5-18) guidelines, and Satir (1964, p. 2).

The purpose of the first few questions was ainly to elicit identifying information from agenoies similar to that which father might seek when looking for a place of treatment for his child, himself, and his family.

Questions \#3 through $\frac{\| 1}{71}$ cover such information as whether an agency is public or private; the age of the children served; the fee, if any; the average wait until the applicant can be seen; and the professional qualifications of the ataff.

The question of the fee, $\# 5$, was included in order to determine which agency's services are financially available to a father with a low income or a large family. In either case no fee, or a nominal fee, would be desirable.

From questions \#6 through \#8 it was hoped scme indication could be obtained of the waiting period of agencies.

Because of the father's work hours the flexibility of agency hours becomes significant. question 12 assessed the availability of evening and weekend hours to the father. Also the extent to which these hours are regularly scheduled or are for emergency counseling only was obtained. Question 13 inquired as to the agency's use of home visits.

The question on the theoretical approach, \#15, was designed to ellcit information on the basic theory or theories utilized in treatment by agencies. One approach, the clinical, encompasses psychodynamio theory. Towle (1954, p. 52) described dynamic behavior as being between three continuously related functional aspects of the personality, namely the 1d, the superego, and the ego. Carter and Stuart (1970, p. 37) 
point out that dynamic theory and therapy places emphasis on complex mental structures and processes and rely mainly on the production of insight, awareness, self understanding, self acceptance and the like, using the interview as the principal medium of treatment.

Behavioral (stimulus-response) or behavior modification entails the learning theory approach as applied to change in maladsptive behavior (Bandura and Walters, 1963, p. 251; and Carter and Stuart, 1970, p. 38). Other approaches might include the Eolectic approach which encompasses a combination of theories.

The basic philosophy, or value system, and the policy, or rules of an organization, may be difficult for the staff to implement fully due to many factors such as limited staff training, proportion of staff to clients, and lack of space and funds. Information in this area was elicited in questions \#16 and \#17 in an effort to assess how possible it is for agencies to carry out their philosophy and policy regarding the father, in actual practice.

Whether a father was in treatment through his voluntary participation or through a court recommendation may have effected his motivation for treatment and therefore data in this area was asked in quest tion \#18. Question \#19 was related to the previous question in that it elicited further discussion of the various factors which are related to the father's accessibility to treatment and his availability during office hours.

Recognition of the disadvantage: to the child of the absence of the father and agencies' provisions for a substitute father were assessed in questions \#20 and \#21. 
The purpose of questions \#22 and \#23 was to bring out the individual views of the eighteen social workers interviewed concerning the father's influence on the child, the effect of his absence, and the desirability of his involvement in the planning and treatment process. Also sought was information on the way in which the social worker saw his agency's role as unique in dealing with the father.

\section{LIMITATIONS}

Karl Pearson, in 1898 noted that no scientific investigation is final; it merely represents the most probable conclusion which can be drawn from the data at the disposal of the writer at the time of writing. A wider range of facts, or a more refined analysis and observation is always possible (Truax and Carkhuff, 1967, p. xiii).

By reason of this being an individual thesis it was necessarily limited in scope and dimension. For example, with more research participants, agencies in the tri-county area or the entire state could be surveyed in order to provide wider range of findings.

An effort was made to make a complete list of agencies and programs serving children with emotional problems in Multnomah County, but no doubt some agencies were inadvertenly omitted. Also, only two agencies were divided into two separate programs. This procedure could have been applied to several other agencies. No attempt was made to use a sampling procedure or a control group.

There are other programs in Multnomah County which are closely related to those selected for this survey such as certain nursery schools and day care facilities who engage social work staff for 
counseling with children and their parents. These programs were not included due to the limitation in time.

As there was considerable variety in the sizes of the selected agencies, an interview with one social worker may have represented only one-tenth of the social work staff while worker in a different agency might have spoken for one-half of the total social work staff. Another approach to the study, which might have offered a greater understanding of paternal views, might have been an interview with fathers of children who were reported by the school to be experiencing behavior problems. Still another approach might have been the examination of agency records. This method might have gained a leas subjective response.

The literature review in Chapter I was not intended to be a systematic and comprehensive and represents only a general view of theory and research on the father's role. A more extensive and systematic survey, no doubt, would have revealed a more complete picture of the many aspects of fathering and the effect of the father's absence on the child. 


\section{CHAPTER III}

\section{ANALYSIS OF THE DATA}

\section{FINDIMGS}

This partioular study attempted to explore the answers to some questions relative to the father in treatment. All data were collected by personal interviews with professional social workers in elghteen selected social service programs. The interviews were completed within a twenty-one day period. The size range of responding agencies was wide with about equal numbers of large and small programs and a considersble gradation in size in these two categories.

All agencies serving emotionally disturbed children, which were listed in the booklet "Where To Turn", and which provide social work services in Multnomah County, were chosen. No consideration, in making the selection, was given to whether these were public or private agencles. In the resultant list of programs there was aimilar number of agencies, that is the list contained eight that were public and ten that were private or voluntary.

A data collection schedule was used in the interview aituation as a general guideline for an informal discussion of each social agenoy's philosophy, policy, and practice in dealing with the father. It was not used in a step by step question and answer process. Adjustments in the content of inquiries were wade to coincide with the structure and purpose of each program. Comments as to the social worker's opinion of 
important or unique aspects of dealing with the father in treatment were encouraged.

\section{Administrative Factors}

The first few questions on the schedule were formulated to obtain descriptive information concerning services avallable to the father and his family from the agenoles. Of the eighteen programs, over one half, or eleven, served children of all ages. Several agenoles carried out specialized programe related to ppecific age groups. For instance, two agencies limited their programs to children in early childhood, one served children in latency, two served both children in latency and in adolescence, and two treated ohildren in adolescence sione. In summary there was a wide spead of age levels served with no age group being left without servioe.

Some agencies offered, as part or all of their service, residential care in the form of an institution or a group home. Several programs offered family counseling service as their one speciflo function while in other programs this treatment was contingent on the participation of one or all members of the family in some other function of the agency auch as financial aid, medical care, or residential care.

In regard to fees for casework service all ten of the private agencies and four of the public agencies reported using a sliding scale. This type of charge enabled the father to pay a fee in proportion to his income and other obligations. These agencies reported that services were provided without cost to those families with very low incomes, with the exception of one small public agency which charged a one dollar minimum fee. The purpose of this small fee was hoperully to give the 
client a sense of aking a contribution and thereby adding to his self esteem. Services in the four remaining agencies were provided without cost. These were large public programs.

In cases where residential care was utilized for the child, due to the high cost involved, most families of low or middle incomes were found to be eligible for "purchase of care" through Public Welfare. In summarizing the fee situation, all of the agencies in the survey seemed to be available financially to the low income father as all but four ageneies used the sliding scale and the remaining four provided counseling without a fee.

An Important area in which the survey attempted to get oome Information was the length of the waiting period a father would encounter upon his application to an agenoy. The majority of the programs were able to see the applioant within a three day to a three week period except when there was an unusually high application rate. At that time the waiting period was longer, sometimes extending to a two or three month period. The few remaining agencies reported that when applications became unusually heavy it was their pollcy to close intake for a period of time. On these occasions no waiting list was kept and clients were referred to other agencies or told to call back in few months.

The survey showed that, of the eighteen participating programs, none saw an applicant immediately except in some of the cases of crisis. Eleven out of elghteen programs had a policy of seeing the person, with an emergency situation, within a three day period.

In summarizing the findinge on the waiting period there seemed to be a serious delay to many fathers who apply for service due to a long 
period of waiting, particularly in seasons of heavy inteke. The policy of more then half of the ageneies to see persons in orisis within a three day period is an indication of the awareness of the importance of the timing factor. Perlman, (1960, p. 171) in speaking of some considerations to be taken at the time of intake, pointed out that it is important to not only give help where it is needed but at the moment in time when stress and motivation are high enough to push a person to reach out for help.

An extensive assessment of the length or quality of service given to the father and his family was necessarily out of the scope of this paper. There were, however, indications frow the interview information that a few agencies were able to give intensive long term treatment and that these were minly specialized programs which regulated their intake In relation to the number of staff members. Most programs, particularly large public programs, were short of staff in propurtion to lollents and were thereby limited in the quantity of service they could offer.

The number of social work taff with an WSW degree was examined since the basic assumption of this paper is that the level of training of the therapist is crucial to the quality of the service given. It was found that while all of the interviewees held an MSW degree, some of the other social work staff members were at the Baccalaureate level or had one year of graduste training. Five out of eighteen programs hod $100 \%$ of their workers at the graduate level. In sumary about half of the total number of social work staff in the selected programs had received an MSW degree.

As the father is generally less available during the day, due to 
his employment, the flexibllity of the working hours of the social work staff is relevant to his involvewent in treationt. A social worker, whose agency was open only from nine to five, commented that these hours caused a hardship for the working olass father who received a reduction in wages for time taken off and in addition was charged a fee at the ageney. The yorking olass father also often found it more difficult to obtein time off than the professional the same social worker, and soveral others, noted that middle class fathers on the other hand were often allowed t1me off from work without loss of income.

Three agencies reported thet their hours were from eight to five on weekdays only. No agencias reported regular hours on Saturday.* Six programs reported being open either one or two ovenings a week on a regularly scheduled basis. Two other agencies were open several week night ovenings at which time group work was held. The evening hours of these eight agencies were arranged at that time to accomadate to the father's working hours. Weekend marathons, held occasionally by one of these agencies, were also conducted at that tiwe to wake the father's attendance wore poseible.

Bleven out of eighteen social workers described their woriking hour as flexible. As professionals they were expected to adjust their hours to best aerve the elient. Therefore they worked some evening and weekend hours and took compensatory time off during the week at their own discretion. This is in contrast to the three agencies whose strict eight to five o'clock hours offered no flexibillty of hours.

\footnotetext{
"It is interesting to note that MDs and DDSs often have office hours on saturday.
} 
One large private agency, which provided group homes as part of their service, noted that the social worker in this setting of ten saw visiting parents on the weekend and therefore was able to counsel a higher proportion of fathers than caseworkers who saw parents only in the office setting on weekdays.

One large public agency which served children of all ages maintained an intake service and a residential facility on a twenty-four hour basis. Five programs engaged an answering service for evening and weekend calls. Inquiries received at these hours were immediately referred to the social worker who was on call. Usually the service given was in the form of information on community wide services available at that hour. bt times help with the admittance of a child to a residential program, on an emergency basiz, was arranged.

In summary the findings on agency hours showed that eleven out of eighteen agencies maintained a position of trying to accommodate their hours to the father's availability. However only six programs had regularly scheduled evening hours and no agencies are open on Saturdays. The inquiry on the use of the home visit revealed that although most of the sooial workers felt that contact with the family in their home could be a valuable service to clients and brought useful information to the social worker, only four reported its frequent use. Nine agencies reported the use of the home calls. The lack of use or infrequent use of home visits was stated to be due to the lack of staff time rather than to the devaluation of the practice.

\section{Asency Philosophy and Programs}

The question on treatment modes was designed to explore the 
frequency of use of the modes and the social workers' views on the relative effectiveness of the methods which involve the father in treatment. The responses indicated that many of the standard methods of treatment (see Appendix D) are employed by the selected agencies in this survey. Most of the social workers felt that all of the methods are valuable in their own right and that their use was determined by the worker according to what was appropriate to the client's situation, the worker's skills, and the time available.

Sixteen programs identified the individual method as one of their major modes of treatment. All of the social workers in these programs used it in conjunction with other modes. One of these agencies described the use of the individual method with the father as an important accompaniment to the conjoint and the marital group methods. Two programs indicated that they used the individual method only occasionally. One of these programs felt that although the individual method could be very effective, it was time consuring and they therefore expended their main effort on specific types of group work.

Golner (1964, pp. 538-539) gave an example of the concurrent use of the individual interview with other methods. The father in the case described was in therapy because of a learning problem of his latency age son. The author explained that the father had apparently never known any other way of life, save that of renouncing his rights of possession and achievement. Appointments that were specifically for him served to acknowledge him as a valuable person. He gradually learned through the casework relationship that he and his opinions were important and as he gained confidence in his masculine identity he was able to help his son. 
A large mority of the social workers intervieved expressed an interest in total fomily group therapy as an effective method of involving the father in trestment even though their particular ageney alght not be able to inelude it in the methods that were used at that time. One interviewee commented about fanily therepy "no one operates in a vacuu - how can you do 1t otherwise?" This worker and one other sociel worker pointed out that Nathan Ackernan and others had advocated family paychotherapy for many years and that in the last ten years this method had received increasing attention from many authore and therapists. S1x agencies which did not use the family group method stated the reason was insufficient staff time or the emphasis on other treatment modes. Two of these ageneles were making plans to inolude the family group method in the future. Three agencies used the method only ocessionaliy and stated that it was a valuable mode but their time was too limited to use it often. Bight programe indicatod that the family group method was one of their major methods of treatmont and one desoribed it as the only mode used frequently.

One therapist explà ined that when he began his work in his present setting, several years ago, his main eaphasis was on the individual trea tment of family members. He began to notice what he felt was wore change in the behavior of his elients who were participating in family therapy and he therefore changed his in emphasis to that method. The fasily group method views the total family as dyefunotional, not just the one child who is Identifted. One of 1 ts goals is to strengthen the father's role. The above mentioned therapist sees the father as an essential person in the family interaction and includes him in every 
session, if possible. It is interesting to note that this is a program whose office hours are from nine to five only, and that the fathers are able to arrange to attend in most cases.

Ackerman (1967, pp. 5-7) recommended family psychotherapy for all stages of the life cycle including childhood, adolescence, and adulthood. He felt that the use of both fanily and individual therapy are fundamenta11y complementary, not oppositional. The needs of both are in the long view profoundly intertwined. Brodey (1967, p. 18) pointed out that therapy with a family one hour and with an individual in another hour gave a fresh perspective to each kind of work.

Responses regarding the use of the conjoint or marital pair counseling revealed that several agencies felt these methods were an ald in helping the man of the family to be a more adequate husband and that thereby his role as a father was strengthened. Agencies with children in various types of residential programs often used conjoint counselins for parents as a preparation for the return of the child to the home. Two interviewees stressed that a strained marital relationship could be the source of a child's emotional disturbance and that in many cases, after an initial interview with the ohild, only the parents were seen for treatment.

Another social worker whose program used conjoint therapy as the main method stated that it was rare when they saw the mother alone (unless there was no father in the home). They found that the father was often more realistic than the mother and that he was more willing to honestly state how he felt. They also found that what the mother conveyed as the father's view was frequently quite different from what the 
father stated for himself.

On this subject Nash (1965, p. 289) cited the findings of Eron et al. who found that independent interviews with both the father and the mother yielded only small agreement between either on their ratings of their child's behavior or on their ratings of their own interactions with their child. The father's reports appeared rather more accurate than the mother's. They felt it was more accurate to interview the fathers themselves ther than to study their wives' perception of their role.

Another agency noted that if the father did not come with the mother at the time of the first interview it could be an indication that communication was poor between the parents. The father was then urged by the agency to attend the counseling sessions.

The survey showed that one program used the conjoint method as its only major counseling* method, eight used it as one of its major methods, four used it occasionally, and five did not employ this mode.

Two agencies held family life groups on occasion and the groups were the responsibility of social workers who specialized in that field. One other agenoy planned for a parent education group for the future. None of the other agencies indicated the use of the parent education group mode.

One agency reported the use of group counseling as its one major mode. The approach of the therapists was Transactional Analysis with the use of some Gestalt Therapy. Persons over twelve were eligible and the subjects covered were wide. One other agency used group counseling

* In this paper I distinguish between group therapy and group counseling (see Appendix D). 
as one of its major modes. Two agencies used it only occasionally. One of these held a group for married couples who were being counseled toward the return of their child to the home. Family and Children's Services of Greater St. Louis (1968, p. 16) noted that group counseling can be advantageous in involving fathers in groups of couples, whereas they may otherwise be hesitant to participate in therapy.

While a majority of agencies reported they did not use the group therapy method, a few did make substantial use of this mode. Two used it occssionally for a matal couples group or for individual parents in a parents group. Another agenoy used it for marital couples in marathon type sessions. They felt the marathon approach belped iron out more problems than short sessions.

Another agency, which reported using group therapy as one of their major modes, also used the marital pair group. They presented to the parents the notion that ohildren's emotional disturbances often are a product of marital problems and asked them to take a look at their own marital interaction. This agency found that although some parents do not remain in this type of therapy, many others do. They also noted that fathers who are resistive to individual treatment at first will of ten start in marital couple groups.

Neither the collaborative nor the concurrent methods were used extensively. Two agencies reported the use of the collaborative method as a mojor mode and four used it on occasion. Of the eighteen agenoles in the survey only three used the concurrent mode as a major method and seven employed it occasionally.

By and large most agencies utilized both the multiple-client 
method which sees various groupings of the family members together and which may include significant other persons, and the combined treatment method. All used both methods as major modes except for eight agencies: which used the methods only occasionally.

When the majority of the agencies saw either the mother and child or the father and child together it happened as a form of multiple client interview rather than specific mode. It is interesting to note that only one agency reported the use of the mother-child mode as a major treatment method and even in that case it was used in addition to many other methods.

In summarizing the treatment modes employed by agencies it appears that the indiridual, multiple-client, and combined treatment modes are used most frequently by the majority of the programs. Some of the other modes such as total family group therapy, marital pair therapy, and group counseling or group therapy, though used only by a minority of the programs are carried out by social workers trained in these modes and are found particularly effective in involving the father. There are indications in the findings that several programs plan for the implementation of these newer modes in the near future and that the mejority of agencies although they do not include those modes in their present treatment plan do recognize their value.

The majority of the social workers interviewed indicated that the theoretical approach varied somewhat between the different members of the social work staff of their agency and that each worker followed the approach he favored or which he felt was best suited for the particular client or family with whom he was working. There were however key areas 
of emphasis. Most of the agencies reported their main approach was the psychoanalytic or dynamic model. Three programs described their approuch as Bolectic - that is the use of various theories without attention to a particular label.

There were varying degrees of the use of the learning theory or behavior modification techniques. Some agencies did not apply these principles in their practice while others used them in a limited manner. Two agencies reported the extensive, but not exclusive use of behavior modification principles and techniques in both residential and counseling situations. These agenoies explained the use of this theoretical approach to parents at intake. Therefore it could be concluded that the father was given an opportunity to decide if he wished his child to enter this type of treatmant. In sumsary it would sppear that there is a wide use of the various theoretical approaches applicable to social work practice.

Various procedures were employed by different agencies to encourage the father's involvement in therapy. One agency phoned or wrote to the father who had not yet become involved to explain that the agency felt that he was a vital member of the family and that treatment, to be successful, must include him.

Two agencies noted that the mother frequently initiated the first contact with the agenoy but that after the therapist emphasized the need for the father's participation she was active in bringing about his attendance at the next session. Satir (1964, p. 5), in speaking of family therapy, commented that the mother may initiate the therapy, however once treatment is under way, the father becomes as involved as she 
does.

One ggency, which made a point of emphasizing the value of the inclusion of the father in treatment, saw the father as having an important influence on the stability and self concept of the mother. They noted that if the father was not in agreement with the goals of therapy he could undermine the agency's program with the family. On this subject Nash (1965, pp. 270-271) clted studies which saw one aspect of the role of the father as that of an emotional support to the mother and saw his influence as profound on the mother-child relationship.

Another program which emphasized the participation of the father identified as unique its parent centered approach. This agency had a policy of not accepting a family for treatment without the father's contract to take part in therapy. The agency found that if sessions were conducted under the assumption that the father was an important part of the family, he too accepted this view.

Seven agencies particularly mentioned that a high percentage of fathers compared to mothers were involved in treatment and stated that it was rare when they did not see the father as well as the mother. In summarizing the agencies' efforts to involve the father in therapy it should be noted that all eighteen programs in the survey includec in treir philosophy the importance of the father's participation in the treatment process. There was however a great difference in the degree of implementation possible to agencies in actual practice due to factors such as high caseloads. Most sooial workers felt it was vital to bring the father into treatment and to involve him from the beginning if possible. 
One agency provided a service that they felt was unique. This was a "homemaker" service which could be an aid to the father in the case of the illness, death, or desertion of the mother, in keeping the family from being split up while he was in the process of making permanent plans for them. Wolff (1969, p. 80) and Stringer (1967, p. 76) pointed out that without some help in the home during a period of upset or grief, the father is often rushed into unsatisfactory plans for the future.

The Father in Treatment

There were considerable differences in the amount of paternal involvement that agencies were able to obtain. All ten agencies who worked with at least a few fathers who were in counseling because of a judicial requirement indicated that the father, under this obligation, was comparatively more resistive than the father who had come for treatment voluntarily.

Lippman (1962, p. 52) commented that often if a court sends the parents of a disorganized family to a clinic for help with a delinquent youngster the parents are distraught, angry, and disillusioned. They are fed up with social agencies and distrust them. The time spent with such parents at the right psychological moment may help them to see the wisdom of allowing the clinic to work with the many problems in the home. The caseworker's interest may be the first evidence that someone is willing to give their problems the consideration they merit. Another situation in which agencies found it hard to involve the father (parents) in meaningful treatment was in cases of child neglect or abuse. Usually these parents were preoccupied with many emotional 
problems of their own and do not respond to overtures to enter counseling. One agency with a residential progran reported that on occasion, if these parents declared an interest in having their ohild enter the program, the agenoy counseled the parents as much as six to eight months prior to a decision on intake in order to determine if the parents were able to work with treatment. Twelve agenoies reported involvement with at least a few of the cases in which neglect or abuse of the child was a factor. Three programs had a high percentage of these cases. One social worker who identified his clientele as inly of the middle class found the fathers, on the whole, to be interested and active members of the treetrent process. This therapist and three other soolal workers expressed the opinion that some resistance in fathers is possibly culturally derived from the time when the view was prevalent that men were strong and that treatment was a sign of weakness. Currently, he noted, this attitude seems to be more of a class view with the working man more inclined to favor this opinion in contrast to the professions 1 man who accepts counseling more readily.

Fourteen agencies made it strikingly clear that on the whole they found the father to be vitally interested in the child's emotional disturbance and in the idea of entering therapy to help resolve the prob1ems. It was not the social workers' contention that the fathers showed no resistance whotsoever to entering treatment, but they wished to point out that the degree of the father's cooperation was significant. One agency particularly stated that they were continually impressed and surprised by the father's motivation to work for constructive change even though for sowe fathers there were real obstacles which had to be dealt 
with such as the difficulty in obtaining time off from work and the loss of income.

In summarizing the elements in the fathers' accessibility to treatment, several factors such as court referral, an scting out child, or an emotionslly inadequate abusive father seemed to have a diminishing effect on the extent of the involvement of the father. On the whole however the father was found to be vitally interested in his child and to be motivated to enter treatment.

The subject of social work contact with the father absent from the home brought a unanimous response from the agencies that each situation required an individual assessment as to what approach, if any, would be appropriate. Many factors concerning the child's current home situation and the father's characteristios required individual consideration. The social workers felt that in some situations the father could offer emotional support to the child or even a needed home.

Five agencies who dealt with a large proportion of deserted, neglected, or abused children who had been placed in residential care commented that the treatment of the father was seldom feasible but that it did prove to be possible in a few instances. In protective service cases, where children remained in their own homes and where the father was absent, the social workers made a point of contacting the father. Iippman (1962, p. 53) commented that when parents are divorced and have remarried, the caseworker attempts to see the parent who lives apart from the child (usually the father). The mother may resist such a plan, particularly if she fears that contact with the father will atir up previous complaints. The caseworker may allay such concern by 
assuring her that she will defend the mother's reputation as a good parent and inform the father that she is seeking information from him to obtain a more complete picture of the child.

One residential program's policy always included the initiation of a conference with the absent father to ascertain his views concerning his child and to assist the child to decide what kind of a relationship he wanted to have with the father. At times there were disagreements between the mother and the father which had to be resolved in some way.

Another program worked mainly with the parent who retained custody of the child (usually the mother) and contacted the other parent only if the parent with custody requested that they do so.

In summarizing the contacts agencies have with the father who is absent from the home it appears that he is seldom in the pioture but it is important to note that in some instances he is contacted and is significantly involved in treatment.

Use of a Supplemental Male Model

A question regarding the agency's efforts to help obtain substitute masculine models for fatherless children was applicable to twelve programs. They responded with an expression of recognition for the need of the surrogate father in some families, but they reported that resources for this service are not easily avallable. Two social workers particularly emphasized the point that more "big brothera" programs were vitally needed. They felt such programs were not available to most agencies. One small agency developed 1ts own program of "college companions" through cooperation with men students of a local university. 
Other resources utilized by social workers to help provide the child with masculine influences are male teachers; recreation counselors in the YMCAs; Boys' Club's teachers; recreation counselors in the YMCA"s Boy's Clubs, Scouts, and so forth; social caseworkers and group workers; friends; and relatives.

All agencies reported about equal numbers of men and women on their social work staff with the exception of one large program which reported more women than men on the staff. Those programs which used one or all of the types of work pointed out that when two therapists worked together the policy was to employ both a man and a women.

In summarizing the use of a supplemental male model for the child it appears that the agencies surveyed recognized the value of using a substitute father figure but that the resources in this a rea need to be developed further.

This chapter has described and summarized the findings of the survey of selected social welfare agencies. The following chapter will draw some conclusions on the more pertinent findings. 


\section{CHAPTER IV}

\section{CONCLUSIONS}

The introduction material in Chapter I of this paper reported on some of the 11terature on fathering. It indicates that there has been a growing trend toward the recognition of the importance of the paternal role. Also there seems to be an increase in the research concerning the father's role in the child's development and on the effeot of the father's absence on the child.

According to Ackerman (1967, p. 7) treatment of the total family unit was a historical necessity because of the growing recognition in. the professions of certain weaknesses in traditional forws of psychotherapy. The evolution of the theory of personality, the quest for a new synthesis in the theory of psychotherapy, new developments in the behavioral sciences, the recognition of the link between social health and mental health, and the crisis of family instability induced by social changes have been factors bringing the changes in treatment methods which increase the involvement of the father.

The primary focus of this descriptive, partially exploratory paper has been on the father in treatment. The conclusions of this chapter relate to the findings obtained from the interviews with social workers in eighteen selected agencies desoribed in Chapters II and III.

One of the more signiflcant findings of the paper concerns the agency hours which the father encounters when he seeks treatment for 
his child and himself. Findings show that only eight agencies schedule evening hours and that these are for only one or two nights a week. These eight agencies and three others reported having flexible hours which did allow evening and weekend hours on occasion but these hours were at the discretion of the social workers and were used mainly for emergency situations. No agency reported being open on Saturday as a general policy. It would seem that there is little adjustment in ageney hours in consideration of the father's working hours, In view of the social workers' stated value of involving the father in treatment, these hours do not seem realistic.

Another finding which seems to be of import is the emerging emphasis on innovative new treatment methods. The findings show that one half of the agencies use family group therapy as one of their major modes of treatment. One of these agencies uses this method exclusively. It is worthwhile to note that several agencies plan to implement the use of this method in the near future or would like to use it but lack staff time and training. Indications are that the father is more accessible in the newer methods which include him in therapy as an essential nember.

A further finding which seemg of significance is the larger degree of resistance to treatment that agencies noted in the father who was in counseling due to a judicial requirement. All ten agencies which work $w$ with these fathers note less motivation on their part. Indications are that the father's voluntary initiation of therapy is related to his cooperation thereafter.

An additional finding is in regard to the possibility of providing 
a substitute male image for the child in the event of paternal absence. A liajority of agenciea reported that few programs such as the big brother program were available in satisfactory numbers. One agency bas evolved Its own program of college companions in cooperation with loosl university. Indications are that there is an urgent need for the development of additional programs modeled on the "big brother" plan.

Findings show that one agency provides " "homemaker" program. This service can be useful in preventing family breakup in the event of the 1IIness or absence of the mother while perwant plans are being made for the family. In spite of the substantial expense of providing this service ageneies would do well to loois into 1 te use.

An Impression gained by the author from the majority of the social workers intervieved was that the father is more willing io initiate treatment and is more motivated to participate in the process than is generally realized. Along with this the author received the impression that wost agencies are convinced of the importance of the father's influence on the child's psychosocial development and do desire to include him in therspy. These are however subjective views and cannot be proven concluaively in this descriptive study.

Further study needs to be undertaken which will examine more precisely the area of the father's role in therapy. Suggestions on areas of further exploration includes the effectiveness of treating the father who is receiving counselling through a court directive, the sbility of innovative new trestment wethods to bring desired results, and the consequences to the child of the father's absence. In follow-up studies intervievees could possibly be the fathers themselves, or sohool age boys, or a random sample of the sooial work staff in agencies. 


\section{BOOKS}

Ackerman, Nathan W. "The Future of Pamily Psychotherapy." Expanding Theory and Practice in Family Therapy. Edited by Nathan W. Ackerman, Frances L. Beatman, and Sanford N. Sherman. New York: Family Service Association of America, 1967.

Ackerman, Nathan W. Treating the Troubled Pamily. New York: Basic Books, Inc., 1966.

Ackerman, Nathan W.; Beatman, Frances L. ; and Sherman, Sanford N., ed. Exploring the Base of Family Therapy. New York: Family Service Association of America, 1961.

Alexander, Franz. Fundamentals of Psychoanalysis. New York: W. W. Norton, 1948.

Bendura, Albert, and walters, fichard H. Social Learning and persorality Development. New York: Holt, Rinehart, anc Winston, 1963.

Benson, Leonard. Fatherhood: A Sociological Perspective. New Yorks Fiandom House, 1968.

Bernard, Sydney E. Fatherless Families: Their Economic and Social Adjustment. Waltham, Mass.: Research Center, Brandeis University, Florence Heller Graduate School for Advanced Studies in Social Welfare, 1964.

Brodey, Warren M. "The Need for a Systems Approsch." Expanding Theory and Practice in Family Therapy. Edited by Nathan W. Ackerman, Frances L. Beatman, and Sanford H. Sherman. New York: F. S. A. A., 1967.

Elkin, Frederick. The Child and Society. New York: Random House, 1960.

English, 0. Spurgeon, and Foster, Constance J. Fathers are Parents, Too. New York: G. P. Putnam's Sons, 1951. 
Inglish, O. Spurgeon and Peareon, Gerald H. J. Fmotionsl Problems of Living. 3rd ed. New York: W. W. Norton, 1963.

Erickson, Erik H. Identity, Youth, and Crisis. New York: Norton and Co., 1968.

Erickson, Erik H. Childhood and Society. 2nd ed. New York: W. W. Norton and Co., 1963.

Freud, Sigmund. Civilization and Its Discontents. Translated and Edited by James Strachey. New York: W. W. Norton, 1961.

Ginott, Haim G. Between Parent and Child. New York: Macmillan Co., 1965.

Glasser, Paul H., and Navarre, Elizabeth. "Structural Problems of the One-Parent Family." Behavioral Saience for Social Workers. Edited by Edwin J. Thomas. New York: The Free Press, 1967.

Goodman, Mary Ellen. The Individual and Culture. Illinois: Dorsey Fress, 1967.

Hollis, Florence. Casework: A Psychosocial Therapy. New York: Piandon House, 1964.

Jones, Eve. Raising Your Child in a Batherless Home. New York: Free Press of Glencoe, 1963.

Josselyn, Irene M. Psychosocial Development of Children. New York: Family Service Âssociation of America, 1948.

Kempslex, tephen W., and Savitsky, Elias. "Training Family Therapists Through Live Supervision." Expending Theory and Practice in Family Therapy. Edited by Nathan w. Ackerman, Frances $L$. Beatman, and Sanford N. Sherman. New York: Family Service Association of America, 1967.

Kien, Ted. The Father's Book. New York: W. Morrow Co., 1968.

Landy, David. "Problems of the Person Seeking Help in our Culture." Social Welfare Institutions. Edited by Mayer N. Zald. New York: Wiley, 1965. 
Lefiaters, E. B. Parents in Moders America. Illinois: Dorsey Press, 1970.

Li ppoan, Hyman S. Irestment of the Child in Deotional Conflict. 2nd ed. Hew York: MeGraw-Hi11 Book Co., 1962.

Naas, Henry 8. "Soclal Casework," Concepts and Methods of Social Work. Sdited by Walter A. Friedlander. New Jeraey: PrenticeEiv11, 1958.

Naiex, Henry w. Three Theorles of Child Developaent. New York: Harper and Row, 1965.

Hesd, Hargaret. "Different Cultural Patterns and Teohnological Change." Ventsl Heslth and Infont Development. Edited by Kenneth Soddy. New York: Besic Books, 1957.

Mitscherlich, Alexancer. oclety Without The Hather. Hew Yoris: Earcourt, Brace and World, 1963.

Ostrovsky, Everett S. Children Without Men. Hew York: Collier, 1962.

Parad, H. J., and Miller, R. R., ed. Eso-Oriented Casevork: jovolems and Perspectives. New York: Fawily Service ssociation of Amerios, 1963.

Perlman, Helen H. Social Casework: A Probles-Solvins Proeess. Chicago: University of Chicago Press, 1957.

Polsky, Howerd. "System as Patient: Client Needs snd Syster Function." The General 8ystems Approach: Contributions Toward Hollstie Conception of Social Work. Edited by Gordon hearn. Wev Yorik: Council on Social Work Education, 1969.

Redl, Fritz, and Winewsn, David. Children Who Hate. Dow York: The Pree Press, 1951.

Fosenbaus, C. Peter. The Hegning of Hadness. Yeu York: Solence House, 1970.

Satir, Virginia M. Conjoint Bamily Theragy. Palo Alto, Colifornia: Selence and Behavior Books, Inc., 1964. 
Sears, Robert R.; Rau, Luoy; and Alpert, Riahard. Identification ane Child learing. California: Stanford University Press, 1965.

Senn, Miton J. E., and Solnit, Alberg J. Problens in Child Behavior and Developsent. Fhiladelphis; Les and Febiger, 1968.

Thorpson, George G. Child Psychology. 2nd ed. Boston: Houghton Miffin Co. , 1962.

Towle, Charlotte. The Learner. in Education for the Professions. Chicego: Untvereity of Chicago Press, 1954.

Fruex, charles B., and Carkhuff, Robert R. Towerd Rffective Counseling and Paychotherepy: Draining and Practice. Chicago: Aldine Publishing Co., 1967.

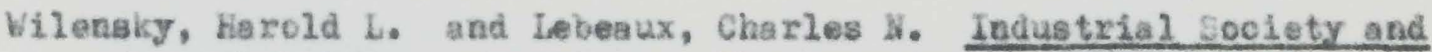
Social welfare. Hew York: The Free Fress, 1965.

White, Robert $W$. The Abnormal Personality. 2nd ed. New York: Ronald Press, 1956.

Wolff, Eula. Children Under Stress. London: Allen Lane, the Penguin Fress, 1969.

Euk, Gerald H. and Boszormenyl-Wagy, IVan, ed., Fanily Therapy and Disturbed Faniliee. California: Science and Behavior Books, 1967.

\section{AFTCLIS}

Áberle, David F. and Naegele, Kaspar D. "Middle Class Fathers" Oecupational Role and Attitudes Tows Children," Amerloan Journel of Orthopgychietry, XXII (Apri1, 1952), 366-378.

Bigner, Jerry 3. "Tathering: Research and Practice Implications." The Fand1y Coordinator, XIX (Ootober, 1970), 357-362.

Billex, Henry B. "A. Wote on Father bsence and Nasculine Development in Lower-Class Negro and white Boys." Child Development, XXXVIII (September, 1968), 1003-1006. 
Carter, Robert D., and Stuart, Richard B. "Behavior Nodification Theory and Practice: A Reply." Social Work, XV, (January, 1970, 37-50.

Christian, Arlene Anne. "Paternsl Involvement in Child Rearing and the Development of Learning Problems in Boys." Smith College Studies in Social Work, an Abstract of a Naster's Thesis, XXXVIII (Novenber, 1967), 43-44.

Erikson, Erik H. "Youth and the Life Cycle." Children, VII (NarchApril, 1960) 43-49.

Feldman, Yonsta. "A Casework Approach Tows Understanding of Emotionally Disturbed Children." Social Work, III (July, 1958), 23-29.

Colner, Joseph H. "Learning Problems and Identity Problems of LatencyAge Boys." Social Casework, XLV (November, 1964), 534-539.

Kahn, Alfred J. "First Frinciples in Planning Coancunity Servicee to Deal with Children in Trouble." Social Service Review, XXX (December, 1956), 4i5-421.

Leichty, Thry ti. "The Effect of Fother-Absence During Early Childhood upon the Dedipel Situation As Reflected in Young Adults." Merr111-Palmer quarterly, VI (July, 1960), 212-217.

Lidz, Theodore; Cornelison, Alice R.; Fleck, Stephen; and Terry, Dorothy. "The Intrafamilial Environment of the Schizophrenic Patient: The Father." Psychlatry, Journal for the study of Interpersonal Processes, XK (November, 1957), 329-342.

MeCcrd, Joah; MeCord, WIlliam; and Thurber, Emily. "Some Brfects of Paternal Absence on Male Children." Jurnal of Abrorrel Peycho100.X. Lankhi1111 (May, 1962), 361-368.

Morse, Joan. "Involving Fathers in the Treatment of Patients with Juvenile Rheumatoid Arthritis." Social Casevori, XIIX (May, 1968) 281-287.

Nash, John. "The Father in Contemporary Culture and Curreat Paychological Literature." Child Development, XXXVI, (March, 1965) 261-297. 
Pederson, Frank A. "Relationships Between Father-Absence and Emotional Disturbance in Male Military Dependents." Merrill-Palmer Quarterly, XI1 (October, 1966), 321-331.

Perlman, Helen Harris. "Intake and Some Role Considerations." Social Casework, XII (April, 1960), 171-177.

Strean, Herbert S. "Role Theory, Role Models, and Caseworks Review of the Literature and Practice Applications." Social Work, XII (April, 1967), 77-88.

Stringer, Elizabeth A. "Homemaker Service to the Single Parent Family," Social Casework, XLVIII (February, 1967), 75-79.

Thomes, Nary Margaret. "Children with Absent Fathers." Journal of Marriage and the Family, XXX (February, 1968), 89-96.

\section{PAMPHLETS}

Family and Children's Service of Greater St. Louis. Guidelines for Selection of Treatment Methods. St. Louis: Family and Children's Service of Greater St. Louis, 1968.

Group for the Advancement of Psychiatry. The Field of Family Therapy. New York: Group for the Advancement of Psychiatry, 1970.

Group for the Advancement of Psychiatry. Integration and Conflict in Family Behavior. New York: Group for the Advancement of Psychiatry, 1968.

The Sienificance of the Father. Four Papers from the F. S. A. A. Biennial Meeting Washington, D. C., April, 1959. New York: Family Service Association of America, 1959.

U. S. Department of Health, Education, and welfare. Office of Child Development, Children's Bureau. Boys in Fatherless Families by Elizabeth Herzog and Cecelia E. Sudia. Washington, D. C.: Government Frinting office, 1970. 
U. S. Department of Health, Education, and Welfare. Social and Rehabilitation Service, Children's Bureau. Research Relating to Emotionally Disturbed Children. Washington, D. C.: Government Printing office, 1968.

0. S. Department of State. Office of Policy Planning and Research. The Negro Family: The Case for National Action, by Daniel P. Moynihan] Washington, D. C.: Government Printing Office, 1965. 
APPGNDIX A

LETTER TO AGENCY ADMINISTRATORS

Mrs. Joanne Robertson

2215 S. W. Taylor's Ferry Road

Portland, Oregon 97219

December 11, 1970

Dear

At the present time I am a second year student in the chool of Social Work at Portland State University. For my thesis requirement I hope to contact all of the social agencies in Multnomah County which provide, as part or all of their program, services to children with social or emotional problems. My study necessitates an interview with a professional social worker at each agenoy, preferrably a supervisor or a person who is involved in direct service to children and their families.

The data collection sheet is brief and requires only general information on agency philosophy, policy, and treatment modalities. The estimated time for completion of the interview is twenty to thirty minutes.

I would like to enlist your cooperation in granting me an interview with one of your social workers. The interviews will be mainly held between 12-28-70 and 1-15-71. The appointment will be at the convenience of the interviewee. If possible please request that the social worker designated for the interview call me at 246-7323 before 12-24-70 to arrange an appointment date and time. If I do not hear from you by December 28th, I will call you. 
If you have any questions please call me at the above phone number. My thesis instruetor is Dr. Guido Pinamonti. He is available for discussion of the requested interview. Should you wish to contact him, he can be reached at the Portland State University School of Social Work, phone 229-4712.

Thank you for your consideration of my request.

Sincerely yours,

(Mrs. Joanne Robertson)

Social Work Student 
APPENDIX B

AGENCIES AND THEIR ADMINISTRATORS WHERE INTERVIEWS WERE

CONDUCTED

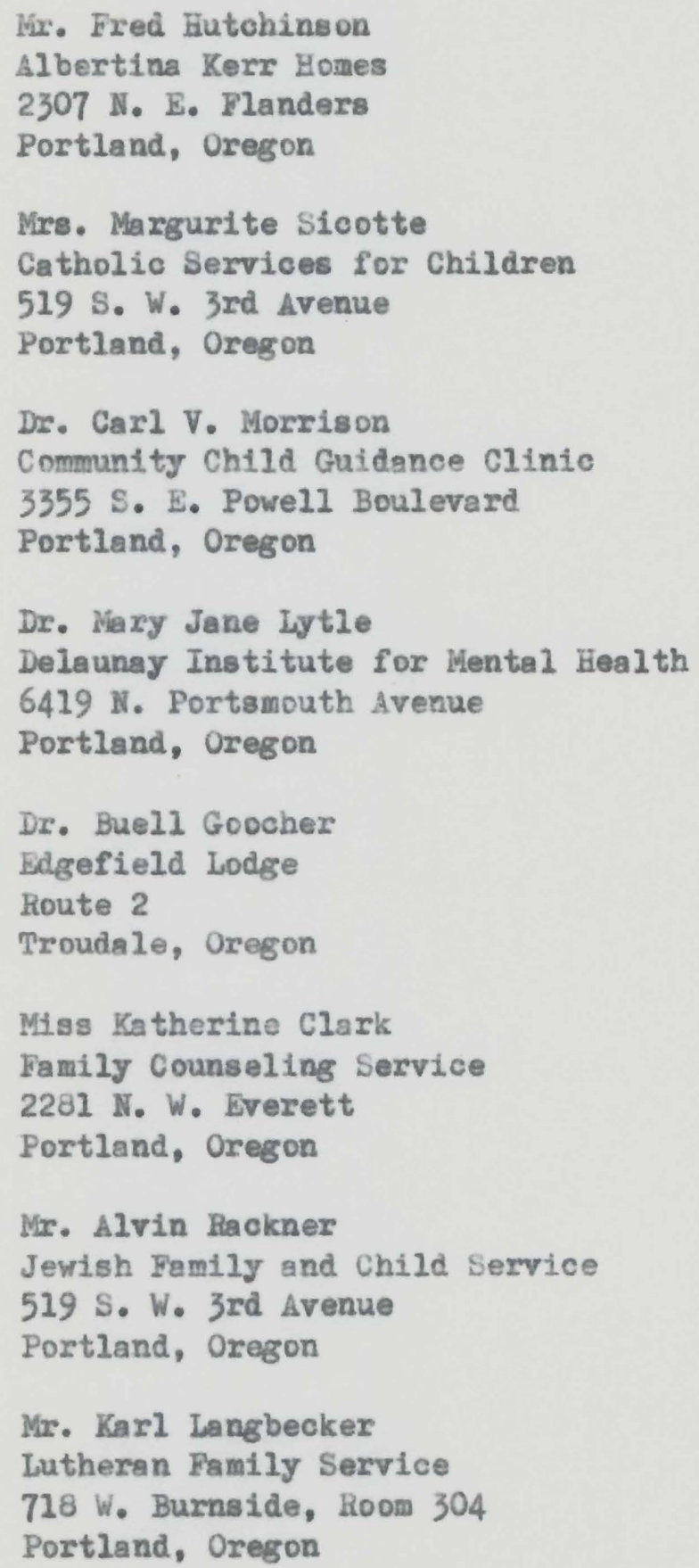




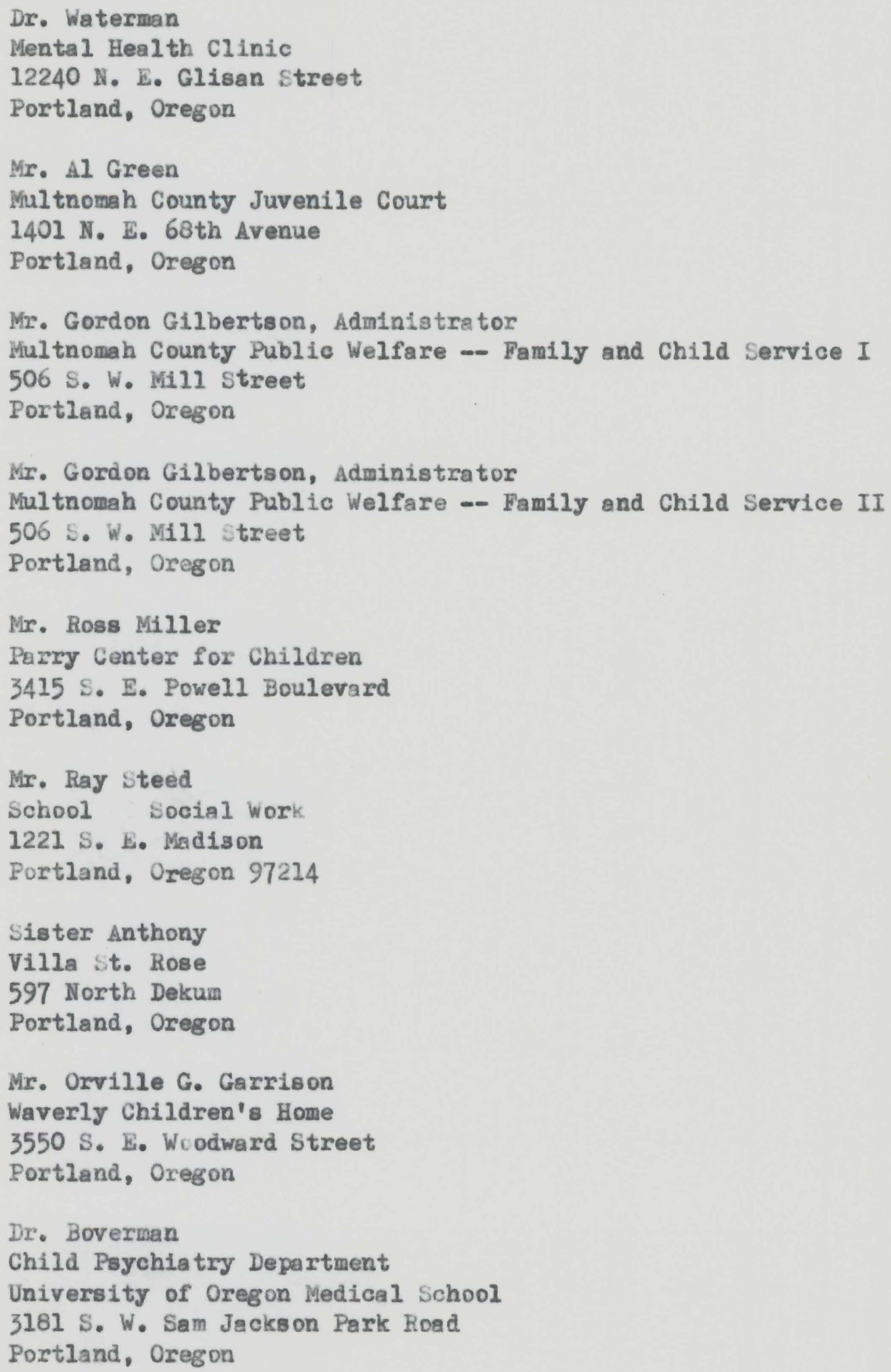


Mr. Les Hunter

Pediatric Department -- Medical Social Workers

University of Oregon Medical School

3181 S. W. Sam Jackson Park Road

Portland, Oregon 
1. Date

2. Name of agency

3. Type of agency: Public Private

4. Age level of child served by agency:

5. Fee: None Sliding scale Set fee Other

6. Average wait between referral or application and f1rst interview

7. Pxoportion of applications rejected because of lack of staff time

8. Agency capacity by number of family cases

9. Staff member interviewed: Name

Training: MSW

$\mathrm{BA}$ or BS

Other

10. Number of social workers who give direct service to children with emotional problems and their families

Proportion of these social workers and their supervisors who have MSW'g

11. Number and training of other staff members who work directly in treatment with same children and their families 
12. Hours of the staff members who counsel families:

8 or 9 A.M. to 5 P.M., M-F only

Evenings How frequently?

Sa turday How frequently?

13. Does stafl make home visits

14. Treatment mode used in therayy and counseling of the child and his family:

\section{Major Occasional Never}
Individual trestment:
Social work ataff
S. W. interviewed

Mother-ohild treatment:

Soclal work staff

S. W. interviewed

Fa ther-ohild trea timent:

Social work staff

s. W. interviewed

Total family group therapy:

Social work staff

S. W. interviewed

Parent group education:

Social work staff

S. W. interviewed

Other

Social work staff

S. W. interviewed

15. Theoretical approah of counselors:

Clinical

Behavior modification

Both

Other 
16. Does the philosophy and policy of the agency include the father's participation in the treatment process?

17. How is this philosophy and policy implemented in actual practice?

18. Type of participation of the father:

Required by agency policy for case acceptance

Mandatory judicial requirement

Encouraged by agency

Not stressed by agency

19. Problems encountered by agencies in involving the father in treatment:

Father's unavallability during office hours

Father's apathy

Father's resistance

Other 
20. If the father is absent from the home:

Is he consulted about the treatment of the child (if

feasible)?

Is he disregarded?

Is the child's need for a supplemental masculine figure such as a relative, neighbor, friend, teacher, or recreation leader discussed with the mother in treatment?

21. Are there male social workers on the staff to provide a masculine model for the child?

22. Is there an approach to the father in treatment that is particularly interesting or unique to your agency?

23. How do you feel personally about the value of involving the father in treatment? 
APPENDIX D

DESCRIFTIONS OF TREATMENT MODES*

The "Individusl" method is the classioal one-to-one approach which focuses on the interpersonal and intrapsychic problems of an individual.

"Mother-child" and "father-child" methods include either the mother or father engaged in joint therapy with the child.

"Total family group therapy", "conjoint family therapy", or "farily psychotherapy" are centered upon the dynamic function of the nuclear family as a unit. wo form of multiple interviewing is the primary treatment technique. Wen indicated, extended family members and key persons with whom there is a close meaningful relationship are included. The main focus is on the interactional process.

The "conjoint" method engages two adults, usually marital partners, in joint interviews throughout the treatment process.

The goal of "Parent group education" is the acquisition of intellectual knowledge and emotionel understanding through which members of the group may modify thinking, attitudes and behavior. They share with others who have similar problems and concerns. The agends represents mejor topics of interest such as parental functioning or child behavior.

"Group counseling" utilizes the group process and works toward increased self-awareness, involvement with others, and changes to more constructive coping patterns. Content of discussion is from the members spontaneoue reveeling of their concerns. Transactional Anslysis and Gestalt Therapy could fit into this category.

"Group therapy" utilizes the group process. Members are selected on the basis of diagnosis, age, and sex to permit heterogeneity. This method is often the choice for adolescents. Treatment involves a working through of problems in depth.

*The description of treatment methode were obtained from Satir (1964, p. 2), Ackerman (1967, p. 4 and p. 15), and The Family and Children's Service of Greater St. Louis (1968, pp. 5-18) guidelines. 
In the "collaborative" method clients are treated by different social workers who communicate with each other on a planned basis.

In the "concurcent" therapy two or more family members are treated individually by the same therapist and in the same general period of time.

The "multiple-client" interview contains several family members rather than the complete family constellation. The individual newbers included may vary from meeting to meeting and persons outside of the nuclear family may at times attend. This method could include the mother-child or father-child modes.

In the "combined" method various types of treatment such as individual, concurrent, conjoint, multiple-client, and family group are used flexibly by one therapist on different occasions. He makes shifts and selections as new diagnostic material and needs emerge. 